\title{
Strategic Options for the Development of Ecotourism in the Danube Delta in the Context of Globalization
}

\author{
Cristina Dima ${ }^{1}$, Sorin Burlacu ${ }^{2, *}$, and Ovidiu Andrei Cristian Buzoianu ${ }^{3}$ \\ ${ }^{1}$ The Bucharest University of Economic Studies, Romania \\ ${ }^{2}$ The Bucharest University of Economic Studies, Romania \\ ${ }^{3}$ National College ,I.L Caragiale”, Romania
}

\begin{abstract}
In Romania, there are major deficiencies in the understanding and especially in the ecological application of tourism, the problem of its unconsciousness and the lack of awareness of the population on this coordinate, which is why people do not realize its intrinsic value for the economy at present, but especially for the future. Each of us should "taste" nature, because living directly in nature, even for a few days, helps to see life in more optimistic colors, breathe better, think more freely, smile more, more credence and courage every second. This article highlighted the importance of sustainable tourism and ecotourism in the Danube Delta, which is an impressive tourist destination, a true paradise for tourists wishing to discover wildlife, a real challenge for nature lovers and maritime beauty region tourism, but also a real scientific interest. The effects of the globalization process have been also noticed at tourism industry level, fact which had generated a series of changes both in production area and even more in the tourism services consume area. Emphasis will be placed on the interdependence links between the development of ecotourism and globalization in the world, which will also contribute to its socio-economic consequences. The strategic options will take into account the impact of the globalization process applied to the case study of the Danube Delta.
\end{abstract}

\section{Introduction}

Sustainable development is that development that guarantees the satisfaction of current needs without compromising the ability of future generations to meet their own needs [1]. The basic idea of sustainability is that of using the planet's natural resources, while protecting and preserving the environment [2]. Development is viewed as a whole, combining economic growth with preserving and improving the environment [3].

The universal value of the Danube Delta has been recognized by its inclusion in the international environment of biosphere reserves under UNESCO's "Man and the Biosphere"

\footnotetext{
* Corresponding author: sburlacu@amp.ase.ro
} 
program in 1970 and over half of its area in the UNESCO Cultural Heritage List, developed by UNESCO in 1972 .

Ecotourism as a community activity is globally considered the fastest growing segment of the tourism industry, growing at rates of $10 \%-12 \%$ per year, which is three times faster than the traditional tourism industry as a whole [4]. More importantly, ecotourism has been embraced by a number of developing countries- that are home to many of the world's rare and threatened species - with a hope of improving their economies in a way that is environmentally sustainable [5].

Ecotourism is not a fashion, it is a necessity of the third millennium [6] which can bring long-term income for both local communities and businesses or segments involved in the sustainable exploitation of these natural resources [7]. It allows the protection of habitats vulnerable to classical tourist exploitation, introduces the knowledge, education, physical and mental relaxation of the tourist on the basis of sensitive, fragile tourist products $[8,9]$.

The aim of the strategy and an elaborated action plan is to promote the Danube region as a tourist destination, focusing on ecotourism as the main form of tourism to the detriment of classical forms of tourism and increasing the role that ecotourism plays in the economic development of the area [10].

Moreover, the marketing strategy for promoting as a tourist destination is an efficient means by which the existing excursions at the level of the area can be made known to the society and which can increase the number of tourists, the length of stay and, implicitly, growth and economic development of the area and increasing the contribution of tourism to the realization of the gross domestic product [11].

\section{Methods}

The strategy development process began with the Diagnostic Report, highlighting opportunities and constraints for the study area. The next step was the Vision Report, which identified an ideal future image of what the community wants the area to be and what potential it has to become. Based on this information, strategic goals emerged. The Needs Assessment Report identified measures and interventions in order to achieve the overall strategic objectives and corresponding sectoral objectives.

The EN report presents the material investment needs, public policy and regulatory reforms, institutional development and technical assistance on each topic. In the realization of the strategic plan the ecotourism indicators were also taken into consideration, namely the ecotourism-specific accommodation structures, respectively the ecotourism circulation in the Danube Delta area, structured on the two levels of tourists - natives and foreigners.

\section{Results}

The most significant physical and ecological feature of RBDD is the vast expanse of wetlands, including freshwater marshes, lakes and ponds, watercourses and canals. Only $9 \%$ of the surface is permanently above the water $[12,13]$. Life for the 10,000 inhabitants in the center of the Delta is a challenge, and access to basic social and economic services is limited. Water transport is often the only option to reach and travel to destinations in the center of the Delta. This strategy represents the next step in the planning of interventions in the Danube Delta area, presenting the main directions of development (objectives, measures and types of interventions). The present study aims to present the current stage of development of this form of tourism at national and international level and to come up with a set of directions that guide the efforts to capitalize through ecotourism of areas where the local nature and culture occupy a central place, in accordance with the requirements 
imposed by the national legislation, as well as by the international conventions to which Romania adhered.

The aim of the strategy is to promote eco-tourism, as a major form of tourism within these destinations, and to increase the role that ecotourism plays in the economic development of these areas and in the prosperity of the local population.

Applying the current principles of developing sustainable tourism in protected natural areas and adjacent areas has led to the emergence of ecotourism as a distinct form of tourism designed to respect the integrity of natural landscapes and ecological biodiversity in line with the requirements of certain segments of tourists who want to spend their holidays in nature and at the same time to create opportunities for local community development [14].

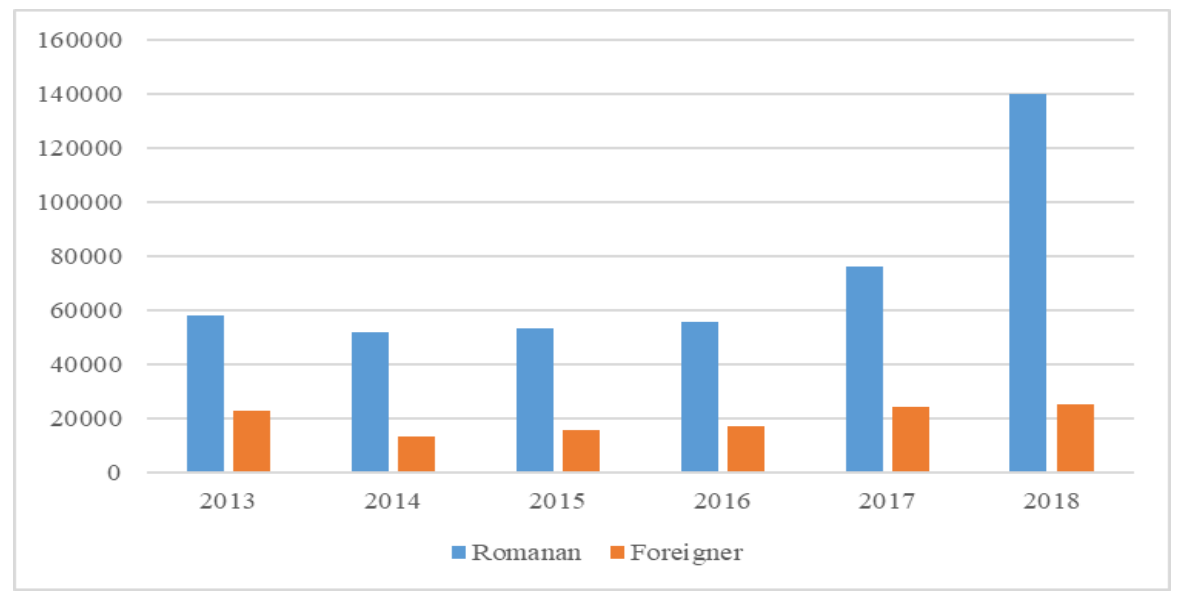

Fig. 1. Total number of tourists in the Danube Delta region (INSSE)

As we can see, there are large discrepancies in the analyzed period, foreign tourists becoming more and more eager for adventures in nature, to taste the values of the natural landscape, as evidenced by the explosive growth of ecotourism flows in the Danube Delta region. At the same time, the last period was characterized by the significant increase in the number of ecotourism-specific accommodation structures (figure 2), which provided tourists with many activities and offers based on natural heritage.

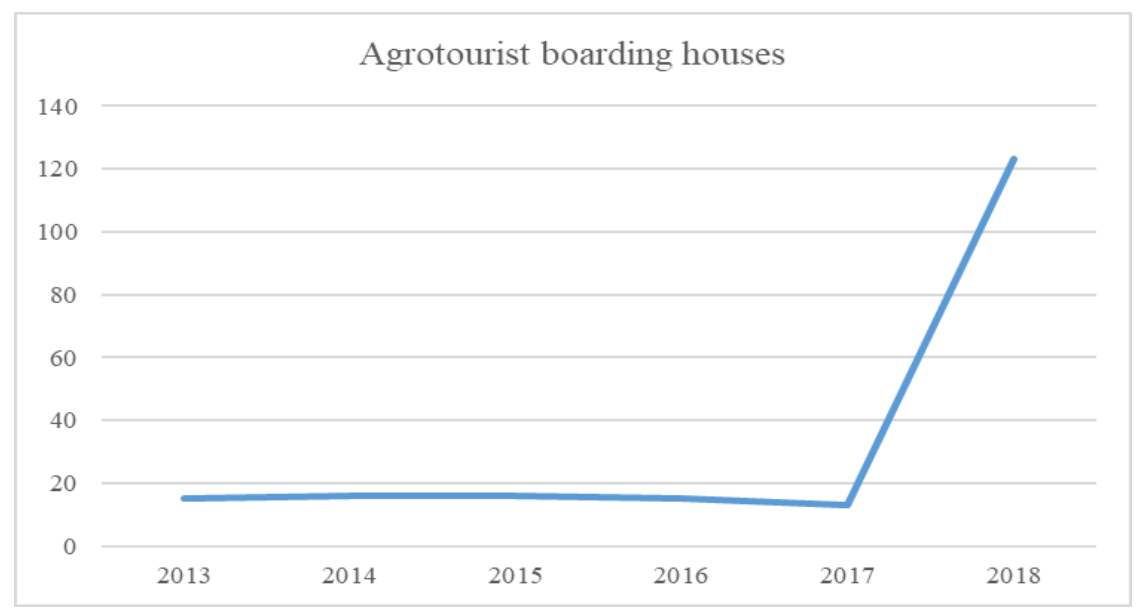

Fig. 2. Agroturist boarding houses (2013-2018) (INSSE) 


\section{Discussion}

The details of this case study as presented in the results contributes to a better understanding of the challenges of the idea of ecotourism as a learning tool for sustainable development. One of the most significant aspects that stands out is that local inhabitants are generally sceptical towards ecotourism as they do not see any profit coming out of it. This matter emerged in previous studies as well [15]. In addition to being sceptical, people living in the area tend to have a negative perception of tourism itself, partly because of the abovementioned reason, partly due to the association of parks with restrictions [16]. This might be a direct consequence of two main factors: a lack of environmental education, and the effects of the current economic crisis the country is facing [17].

Despite the unique combination of natural and cultural resources in the world, the 24 tourist routes approved by the ARBDD (of which 19 on water and 5 terrestrial), the 7-8 month / year season and competitive prices (an average of only 30-50 euro / night for accommodation), the Danube Delta officially attracted only 58,000 tourists in $2013(15 \%$ more than in 2012), of which 60\% were foreigners (Germans, Italians, Dutch, Moldavians, etc.), but experienced a continuous and spectacular development in the period 2017-2018, due to the improvement of accommodation structures, but also to the promotion of ecotourism.

Local tourism entrepreneurs and international tourism agencies have identified the following weaknesses in the local tourism industry: insufficient and incoherent promotion measures, especially for foreign markets; the lack of a tourism development strategy and a brand manual; lack of effective communication and coordination between the different players with competences and skills in the field of tourism; lack of support services for private operators in the field of tourism; tourism infrastructure and poorly developed visitors; important issues in the area that prevent some agencies from further promoting Delta such as poaching, flood disasters, limited access and poor infrastructure of public services, etc .; lack of the institutional framework for the successful management of the Danube Delta as a destination.

\subsection{The product and the eco-tourism brand Danube Delta}

Ecotourism services will be provided, mostly by the local population. Thus, a campaign for information, inclusion and even motivation of the locals to become part of the tourism industry is necessary. It will also train future hosts or providers on how to organize tourism and deliver services effectively. Consideration will be given to how to treat tourists, hygiene, cooking and eating, ecology, environmental protection and consistency. Of the Danube Delta are practiced several types of tourism involving: fishing, bird-watching, resting, boating, swimming, fotosafari, canoeing, hunting, scientific activities, or research.

Taking into consideration the extremely valuable natural environment existing in RBDD, we propose the following types of tourism:

- $\quad$ specialized tourism for ornithologists, botanists, ihtiologists, geographers, etc.;

- $\quad$ special youth programs for knowledge, understanding and appreciation of nature;

- $\quad$ itinerant, practiced either individually or through organized excursions;

- $\quad$ stay for rest, in an unpolluted natural environment, benefiting from the conditions and the hospitality of the place;

- nature-aware tourism, which besides nature can include activities such as birdwatching, photo-safari, canoe, etc.

- adventure tourism, having both fun and educational purposes, promoting the knowledge and protection of the environment through its proposed activities.

- heliomarine cleansing on the beaches of Sulina, Sfântu Gheorghe and Portiţa.

- $\quad$ sport fishing. 
The development of tourism in the area, as well as its actual practice, are regarded as an indissoluble system consisting of three major components: ecological, economic and social component [18]. The three components are in a direct and permanent interaction, the changes occurring in one having direct repercussions in the other.

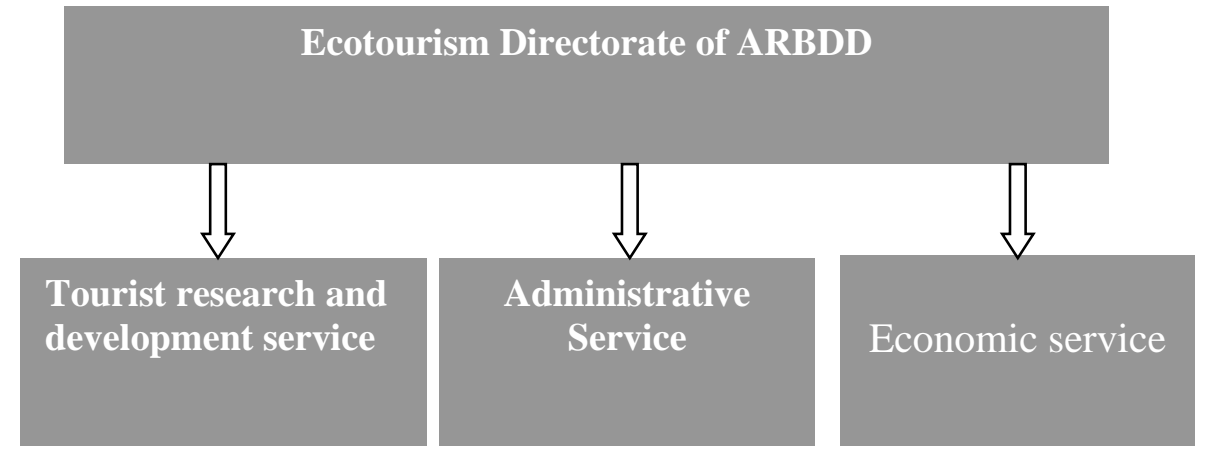

Fig. 3. Structura direcţiei ecoturistice din cadrul ARBDD (ARBDD)

\subsection{Implementation of the development plan}

Starting from the objectives proposed in the plan, we divided the implementation process into two main components, as follows:

- Ecotourism infrastructure in RBDD-Objective: Creating an infrastructure

Table 1. Implementation of the tourism infrastructure development process in RBDD

\begin{tabular}{|l|l|l|}
\hline Activities & Responsible & Time \\
\hline $\begin{array}{l}\text { Inventory and arrangement of structures } \\
\text { accommodation }\end{array}$ & Department ecotourism & 1 Year \\
\hline Inventory and arrangement of structures of food & Department ecotourism & 1 Year \\
\hline $\begin{array}{l}\text { Other structures / equipment (pleasure, landing, } \\
\text { transport, etc.) }\end{array}$ & Department ecotourism & 6 Months \\
\hline Information centers, Panels, signs & Department ecotourism & 6 Months \\
\hline
\end{tabular}

- Achieving ecotourism products - Objective: genuine tourist, specific RBDD

Table 2. Implementation of the ecotourism product development process

\begin{tabular}{|l|l|l|}
\hline \multicolumn{1}{|c|}{ Activities } & Responsible & Time \\
\hline Carrying out studies marketing & \multicolumn{1}{c|}{ AER } & 2 Months \\
\hline Assessment of potential sightseeing & Department ecotourism & 6 Months \\
\hline Creating ecotourism services and products & AER \& Department ecotourism & 6 Months \\
\hline
\end{tabular}

\section{Conclusion}

Ecotourism has developed rapidly over the last decades. Although it has the potential to positively influence the natural and social environment in which it unfolds, it can be as damaging as mass tourism if it is not properly organized. Although some details vary, most ecotourism definitions reflect a distinct form of tourism, which meets four basic criteria: it 
takes place in natural and cultural spaces, involves conservation measures, encourages local community involvement and supports the welfare of locals [19].

Ecotourism is a market niche in tourism in natural areas, which has been impressive in recent decades [20]. It tends to become an independent market segment under the influence of factors such as the aging of the population, the preference for travelers to choose educational holidays, enriching their existence, their desire to escape in the middle of nature, to be active and spend a good time with friends or family, etc.

Unity coordination of efforts and investments is needed in order to implement ecological policies and sustainable management in RDBD. Achieving the sustainable exploitation objective requires annual inventory and exploitation research and setting sustainable management tactics (output control - maximum catch and / or input control maximum fishing effort), responsive to the efficiency of measures and response dynamics fish populations on exploitation but also to natural variations in environmental factors or pollution. Natural resources in the Danube Delta are particularly attractive from an economic point of view and provide the premises for diversified economic activities.

\section{References}

1. S. Brandt, C. Buckley, A global systematic review of empirical evidence of ecotourism impacts on forests in biodiversity hotspots, Current Opinion in Environmental Sustainability Volume 32, 112-118 (2018)

2. F. Bran, C. V. Rădulescu, D. A. Bodislav, S. Burlacu, The anthropic pressure on the forest space. dysfunctions and risks in romania. Quality-Access to Success, 20 (2019)

3. M. D. Negescu Oancea, S. Burlacu, O. A. C. Buzoianu, M. Mitrita, A. Diaconu, Strategic options for the development of ecoturism in the Dornelor County. The USV Annals of Economics and Public Administration, 19(1), 21-28 (2019)

4. H. R. O'Rourke, Economic History and Contemporary Challenges to Globalization, The Journal of Economic History (2019)

5. A. Galli, K. Iha, M. Halle, H. El Bilali, F. Grunewald, Mediterranean countries' food consumption and sourcing patterns: An Ecological Footprint viewpoint, Sci. Total Environ., 578, 383-391 (2017)

6. M. Honey, Ecotourism and Sustainable Development: Who owns paradise? (Island Press, Washington D.C., 2008)

7. F. Bran, C. Alpopi, S. Burlacu, Territorial Development-Disparities between the Developed and the least Developed Areas of Romania. LUMEN Proceedings, 6(1), 146-155 (2018)

8. I. Istrate, Implicaţii economice asupra protecţiei mediului, Revista Tribuna Economică, Bucureşti, 2 (2002)

9. C. V. Rădulescu, D. A. Bodislav, S. Burlacu, Demographic explosion and IT governance in public institutions. Managerial Challenges of the Contemporary Society. 11(1), 18 (2018a)

10. L. Linsi, K. Mugge, Globalization and the growing defects of international economic statistics, Journal Review of International Political Economy, 26, 361-383 (2019)

11. S. Burlacu, A. Profiroiu, P. C. Vasilache, Impact of demography on the public finance of the European Union. Calitatea, 20(S2), 136-138 (2019)

12. F. Bran, Factori de poluare a Deltei Dunării, Revista Tribuna Economică, Bucureşti, 1 (2004) 
13. F. Bran, Activităţi cu impact asupra ecosistemelor Deltei Dunării, Revista Tribuna Economică, Bucureşti, 48 (2004)

14. M. S. Mancini, A. Galli, L. Coscieme, V. Nicolucci, F. M. Pulselli, Exploring ecosystem services assessment through Ecological Footprint accounting, Ecosyst. Serv., 3, 10. Mogoria N., 2018, Determinants of Gender Willingness to Participate in Co-Management of Ecotorism Resources: The Case of Kisumu County, International Journals of Scientific Research and Management, 164-17 (2018)

15. E. Mondino, Ecotourism as a learning tool for sustainable development. The case of Monviso Transboundary Biosphere Reserve (Italy, Taylor\&Francis Online, 2018)

16. C. V. Rădulescu, R. C. Dobrea, S. Burlacu, The business management of distress situations, In the 12th International Management Conference "Management Perspectives in the Digital Era", 1, 741-747 (2018b)

17. S. Burlacu, D. A. Bodislav, C. V. Rădulescu, E-Commerce and Global Food Resources. Managerial Challenges of the Contemporary Society, 11(2), 48 (2018)

18. F. Ioniţă, S. Burlacu, A. Gaidargi, Modern Approaches of the Management of Alternative Trade Systems. Review of International Comparative Management, 52, 473-480 (2009a)

19. F. Ionita, M. Ursacescu, S. Burlacu, Public services as poles of regional competitiveness in sustainable development. Revista de Management Comparat International/Review of International Comparative Management, 10(3), 552-565 (2009b)

20. L. Ruhanen, The prominence of eco in ecotourism experiences: An analysis of postpurchase online reviews, Journal of Hospitality and Tourism Management, 39, 110116 (2019)

21. R. Bianchi, The political economy of tourism development: A critical review, Annals of Tourism Research, 70, 88-102 (2018)

22. I. Jianu, I. Dobre, D. A. Bodislav, C. V. Radulescu, S. Burlacu, The implications of institutional specificities on the income inequalities drivers in European Union. Economic Computation and Economic Cybernetics Studies and Research, 53(2), 59-76 (2019) 